\title{
Pengetahuan dan Sikap Tentang Perilaku Seksual Berisiko Remaja Sekaa Teruna Teruni di Daerah Urban dan Sub Urban Bali
}

\author{
Moh Fairuz Abadi ${ }^{1}$, Dyah Pradnyaparamita Duarsa² \\ ${ }^{1}$ STIKES Wira Medika Bali, Jl. Kecak No 9A Gatot Subroto Timur Denpasar, telp/fax : 0361 427699, \\ ${ }^{2}$ Universitas Udayana, Jalan P.B. Sudirman, Dangin Puri Klod, Kec. Denpasar Bar., Kota Denpasar, Bali 80234 \\ TIp / Fax: +62 (361) 701812 / +62 (361) 701907 \\ Korespondensi: ${ }^{1}$ zabadnews@gmail.com, ${ }^{2}$ mita_budi@hotmail.com
}

Submisi: 16 November; Revisi: 15 April 2020; Penerimaan: 15 September 2020

\begin{abstract}
Background: Sexual risk behaviors in teenagers, could be a serious problems in health. Geographical clould be influence knowledge and attitudes Sekaa Teruna Teruni is a Balinese youth organization, they can be found in all traditional villages.

Objective: The research aim's to find out the knowledge and attitudes of Sekaa Teruna Teruni in Urban and Sub Urban areas about risky sexual behavior.

Method: This is an cross-sectional study, respondents are 241 teenagers (15-21 years) sampling methode is consecutive, variables were measured using a questionnaire that had been tested before, analysis uses non-parametric mann whitney.

Result and Discussion: The results showed that $\mathrm{p}$ score for knowledge and attitudes $<0.05$ its means that there are significant.

Conclusion: The level of knowledge and attitudes of respondents at the Urban location is higher, that because the flow of information and the organizational activities, efforts are needed to increase knowledge and attitudes especially at the Sub-Urban.
\end{abstract}

Keywords: Risky sexual behavior; Sekaa Teruna Teruni

\begin{abstract}
ABSTRAK
Latar Belakang: Perilaku seksual berisiko remaja dapat mengakibatkan gangguan pada kesehatan fisik, mental dan sosial. Keruangan geografis diduga mempengaruhi pengetahuan dan sikap remaja. Sekaa Teruna Teruni adalah organisasi kepemudaan masyarakat Bali. Organisasi ini terdapat pada seluruh desa adat atau banjar.

Tujuan: Tujuan penelitian untuk mengetahui pengetahuan dan sikap remaja Sekaa Teruna Teruni di daerah Urban dan Sub Urban tentang perilaku seksual berisiko.

Metode: Jenis penelitian ini adalah cross-sectional, responden remaja berusia 15-21 tahun sejumlah 241, sampling secara konsekutif, variabel diukur menggunakan kuesioner yang telah diuji validitas dan realibilitasnya. Analisis data menggunakan non parametrik mann whitney. Hasil dan Pembahasan: Hasil penelitian menunjukkan nilai p pengetahuan dan sikap $<0.05$ artinya ada perbedaan bermakna.

Kesimpulan: Tingkat pengetahuan dan sikap responden pada lokasi Urban lebih tinggi dibandingkan dengan Sub Urban, fenomena tersebut dipengaruhi oleh arus informasi dan kegiatan organisasi. Diperlukan upaya peningkatan pengetahuan dan sikap khususnya pada Sekaa Teruna Teruni di daerah Sub Urban.
\end{abstract}

Kata kunci: Perilaku seksual berisiko; Sekaa Teruna Teruni 


\section{PENDAHULUAN}

Masa remaja adalah suatu periode tumbuh kembang dengan sifat yang khas, yaitu keingintahuan yang besar, menyukai petualangan, tantangan serta memiliki karakter cenderung berani menanggung resiko atas perbuatannya, padahal perbuatan tersebut seringkali dilakukan tanpa melalui pertimbangan yang matang. Perilaku seksual berisiko adalah aktivitas seksual pranikah yang dilakukan secara sadar oleh remaja sehingga mengakibatkan terganggunya kesehatan secara fisik, mental dan sosial remaja. Risiko reproduksi meliputi terjadinya KTD (Kehamilan Tidak Diinginkan), aborsi dan IMS. ${ }^{4}$

Sekaa Teruna Teruni adalah organisasi sosial masyarakat Bali yang berada pada tataran desa adat atau banjar (Sanjaya, 2017). Sekaa Teruna Teruni beranggotakan remaja belum menikah, Sekaa Teruna Teruni memiliki peraturan organisasi (Awigawig), organisasi tersebut dipimpin Keliang (Ketua), dibantu oleh Penyarikan (Sekretaris) dan Petengen (Bendahara) dan memiliki perangkat organisasi yang disebut dengan Pesayahan. Keanggotaan Sekaa Teruna Teruni bersifat wajib bagi remaja asli setempat, memiliki sanksi sosial, berada dibawah pembinaan stuktural Desa Adat (Pakraman) dan dalam pantauan ruang figur serta tokoh masyarakat. ${ }^{4}$

Berdasarkan pola keruangan suatu wilayah, maka dapat dijumpai wilayah Urban (perkotaan) dan Sub Urban (wilayah pinggiran kota hingga mencapai wilayah kota/penglaju), pola keruangan geografis tersebut diduga mempengaruhi kehidupan remaja, hal ini disebabkan karena adanya perbedaan karakter fisik dan non fisik, selanjutnya dijelaskan bahwa aspek fisik berkaitan dengan infrastruktur sedangkan aspek non fisik mencakup sifat, tradisi dan segregasi sosial.
Tujuan penelitianiniadalahhuntukmendapatkan informasi tentang bagaimana pengetahuan dan sikap remaja Sekaa Teruna Teruni pada daerah Urban dan Sub Urban, Informasi tersebut diperlukan dalam rangka untuk mendapatkan gambaran tentang perilaku remaja, sebagai base line penelitian yang berkaitan dengan kesehatan reproduksi remaja.

\section{METODE}

Jenis Penelitian penelitian ini adalah studi crosssectional . Variabel penelitian adalah pengetahuan dan sikap tentang perilaku seksual berisiko. Responden dalam penelitian ini adalah remaja Sekaa Teruna Teruni yang berusia 15-21 tahun. Jumlah responden dalam penelitian ini adalah 241 responden yang berasal dari 4 organisasi Sekaa Teruna Teruni dari daerah Urban dan 4 dari daerah Sub Urban.Teknik samping dilaksanakan secara konsekutif. Pengetahuan dan Sikap diukur dengan menggunakan kuesioner yang telah diuji validitas dan realibilitasnya. Teknik analisis statistik yang digunakan adalah non parametrik mann whitney.

\section{HASIL DAN PEMBAHASAN}

Pada bagian ini dibahas karakteristik sosiodemografi responden. Karakteristik responden yang di teliti adalah gender, usia, tempat tinggal, dan aktivitas. Hasil uji statistik menunjukkan bahwa tidak ada perbedaan yang bermakna antara remaja Sekaa Teruna Teruni di daerah Urban dan Sub Urban (nilai $\mathrm{p}>0.05$ ). Hal ini berarti bahwa, karakteristik sosiodemografi antara kedua kelompok adalah setara. Hasil uji disajikan pada Tabel 1. 
Tabel 1. Karakteristik Responden Berdasarkan Sosiodemografi pada Remaja Sekaa Teruna Teruni di Daerah Urban dan Sub Urban

\begin{tabular}{lccccc}
\multicolumn{1}{c}{ Karakteristik } & Urban & (\%) & Sub Urban & (\%) & p \\
$\begin{array}{l}\text { Gender } \\
\text { Laki-laki }\end{array}$ & 56 & 23.24 & 91 & 37.76 & 0.09 \\
$\quad \begin{array}{l}\text { Perempuan } \\
\text { Umur (tahun) }\end{array}$ & 46 & 19.09 & 48 & 19.9 & \\
$\quad \mathbf{1 5 \leq}$ & 4 & 1.66 & 9 & 3.73 & 0.6 \\
$\mathbf{1 6 - 1 9}$ & 60 & 24.90 & 77 & 31.95 & \\
$\mathbf{2 0 +}$ & 38 & 15.77 & 53 & 21.99 & \\
Tempat tinggal & & & & & \\
$\quad$ Bersama orang tua & 102 & 42.32 & 135 & 56.01 & 0.08 \\
$\quad$ Bersama saudara & 0 & 0.00 & 4 & 1.65 & \\
Aktivitas & & & & & \\
$\quad$ Sekolah & 71 & 29.46 & 101 & 41.90 & 0.6 \\
Bekerja & 31 & 12.86 & 38 & 15.77 & \\
\hline
\end{tabular}

Jika ditinjau dari karakteristik gender, maka diketahui bahwa mayoritas remaja yang berpartisipasi aktif dalam kelompok STT adalah remaja laki-laki. Masyarakat di Bali menganut sistem patrilineal, pada tatanan struktur sosial budaya (adat) masyarakat Bali pihak laki-laki merupakan penerus garis keturunan keluarganya (ayahnya). ${ }^{11}$ Hasil penelitian tentang "Hubungan Antara Rasa Komunitas dan Komitmen Organisasi dengan Kohesivitas Kelompok pada Anggota Sekaa TerunaTeruni di Badung" menemukan bahwa partisipasi dan kehadirannya anggota laki-laki dalam kegiatan STT lebih banyak dibandingkan anggota perempuan. ${ }^{10}$ Hal ini berkesesuaian dengan hasil penelitian ini.

Berdasarkan Tabel 1 diketahui bahwa sebagian besar remaja Sekaa Teruna Teruni termasuk masuk pada rentang umur 16-19 tahun, keudian diikuti oleh rentang umur 20 tahun keatas dan hanya sedikit responden berusia kurang dari 15 tahun. Peneliti beropini bahwa variasi rentang umur tersebut didasarkan pada peran organisasi Sekaa Teruna Teruni di masyarakat, sebagai organisasi kepemudaan, Sekaa Teruna Teruni memerlukan individu dengan kemampuan berpikir untuk memahami, menganalisis situasi yang kompleks, serta mulai terlibat pada peran individu dewasa, yaitu berorganisasi, sehingga rentang umur remaja pertengahan diperlukan utuk terlibat aktif menjalankan dan menjadi bagian dari organisasi.
Secara psikologis, remaja 16-19 tahun telah mengalami perkembangan kemampuan berpikir, sehingga lebih mampu mengarahkan diri sendiri (self-directed), Oleh karena itu ditemukan bahwa remaja fase pertengahan dominan sebagai responden dalam penelitian di organisasi Sekaa Teruna Teruni. ${ }^{5}$

Selanjutnya ditemukan bahwa mayoritas remaja Sekaa Teruna Teruni tinggal bersama orang tua mereka. Penelitian tentang "Optimalisasi Peran Sekaa Teruna Teruni dalam Mendukung Terwujudnya Tata Kelola Pemerintahan Desa yang Baik Melalui Gerakan "STT Kawal Desa", menjelaskan bahwa keanggotaan STT bagi para remaja banjar setempat merupakan suatu kewajiban bagi seorang remaja Bali, meskipun remaja tersebut sedang bekerja di luar daerah atau di luar negeri. ${ }^{7}$ Selanjutnya dijelaskan bahwa menjadi organisasi Sekaa TerunaTeruni merupakan syarat utama untuk menjadi bagian dalam organisasi Desa Adat. ${ }^{7}$ Berdasarkan data tempat tinggal dan penelitian diatas peneliti menyimpulkan bahwa remaja STT sebagai responden dalam penelitian telah memenuhi kategori keanggotaan STT. Hal ini sesuai dengan hasil penelitian yang menunjukkan bahwa tidak dijumpai responden yang kost/kontrak (pendatang).

Selanjutnya diketahui bahwa mayoritas remaja Sekaa Teruna Teruni adalah remaja bersekolah. 
Data Angka Partisipasi Sekolah (APS) kota Denpasar untuk remaja usia 13-15 tahun adalah $99.17 \%$, untuk remaja usia 16-18 tahun adalah $73.10 \%$ dan pada remaja 19-24 tahun mencapai 34.24 \%. Jika ditinjau berdasarkan jenjang pendidikan, maka diketahui bahwa responden yang sedang menempuh pendidikan di Perguruan Tinggi lebih banyak jumlahnya dibandingkan dengan responden di Sekolah Menengah. Berdasarkan data tersebut peneliti menyimpulkan bahwa responden yang terlibat dalam penelitian ini relevan dengan data Angka Partisipasi Sekolah (APS) tahun 2018. ${ }^{2}$

Pada tabel 2 disajikan tentang hasil uji uji normalitas data sebagai prasyarat pemilihan uji selanjutnya. Berdasarkan nilai $\mathrm{p}$ diketahui bahwa data skor pengetahuan dan sikap tidak berdistribusi normal $(p<0.05)$. Uji normalitas data disajikan pada Tabel 2.

Tabel 2. Uji Normalitas Data Pengetahuan dan Sikap

\begin{tabular}{lccc}
\multicolumn{1}{c}{ Variabel } & Mean & SD & $\boldsymbol{p}$ \\
Pengetahuan & 57.30 & 19.25 & 0.00 \\
Sikap & 24.65 & 8.40 & 0.00 \\
\hline
\end{tabular}

Berdasarkan Tabel 2, maka untuk membuktikan hipotesis penelitian dilakukan uji non parametrik mann whitney. Pada Tabel 3 disajikan hasil uji non parametrik mann whitney pada variabel pengetahuan dan sikap responden berdasarkan daerah Urban dan Sub Urban.

Tabel 3 . Pengetahuan dan Sikap Remaja Sekaa Teruna Teruni di Daerah Urban dan Sub Urban

\begin{tabular}{lcccc}
$\quad$ Variabel & $\boldsymbol{N}$ & Mean & Mean Rank & $\boldsymbol{p}$ \\
Pengetahuan & & & & \\
$\quad$ Urban & 139 & 62.02 & 137.17 & 0.002 \\
$\quad$ Sub Urban & 102 & 53.83 & 109.13 & \\
Sikap & & & & \\
$\quad$ Urban & 139 & 27.17 & 136.26 & 0.004 \\
Sub Urban & 102 & 22.80 & 109.81 & \\
\hline
\end{tabular}

Berdasarkan Tabel 3 diketahui bahwa nilai $p$ $=0.002$ untuk pengetahuan dan $p=0.004$ untuk sikap, nilai $p<0.05$ artinya pengetahuan dan sikap remaja Sekaa Teruna Teruni di daerah Urban dan Sub Urban berbeda bermakna. Berdasarkan nilai mean diketahui bahwa pengetahuan responden pada lokasi Urban lebih tinggi dibandingkan dengan Sub Urban. Tingkat pengetahuan remaja dipengaruhi oleh faktor internal dan eksternal. Faktor internal meliputi semua sifat, bakat, potensi diri dan faktorfaktor yang berhubungan dengan herediter (gen), sedangkan faktor eksternal merupakan faktor yang berasal dari luar diri remaja, diantaranya lingkungan geografis (Panuju, 1999). Berdasarkan teori tersebut dapat dijelaskan bahwa lingkungan geografis merupakan faktor yang mempengaruhi pengetahuan remaja tentang perilaku seksual berisiko. Peneliti beropini bahwa fenomena tersebut dipengaruhi oleh akses informasi, akses informasi di daerah Urban dinilai lebih baik dibandingkan dengan kawasan Sub Urban, hal ini berkesesuaian dengan hasil penelitian yang menjelaskan bahwa arus informasi mempengaruhi perbedaan pengetahuan remaja tentang kesehatan reproduksi remaja. ${ }^{9}$

Selanjutnya diketahui bahwa nilai mean sikap pada remaja Sekaa Teruna Teruni di lokasi Urban lebih tinggi dibandingkan daerah Sub Urban. Pembentukkan sikap dipengaruhi oleh sumber sikap, artinya pengalaman langsung responden dan pengalaman orang lain yang disekitarnya menjadi dasar pembentukan sikap individu, kemudian pembentukkan sikap juga dipengaruhi oleh adanya intensitas yang ajeg dalam bentuk perhatian terhadap objek tertentu. ${ }^{1}$ Peneliti beropini bahwa bahwa masyarakat Urban memiliki terkondisikan pada keadaaan yang lebih, heterogen, dinamis, dan secara kultural lebih terbuka. Pada penelitian ini ditemukan bahwa remaja Sekaa Teruna Teruni di daerah Urban telah memiliki kesadaran tentang pentingnya edukasi kesehatan reproduksi di bandingkan dengan Sub Urban, kesadaran tersebut diwujudkan dalam bentuk program kerja organisasi yang berkaitan dengan kesehatan reproduksi yaitu tentang HIV/AIDS, NAPZA, dan seks bebas, kegiatan 
tersebut dilaksanakan dengan mengundang narasumber dan pihak terkait secara periodik. Upaya peningkatan kesehatan reproduksi remaja Sekaa Teruna Teruni di daerah Urban sudah bersifat aktif sedangkan di daerah Sub Urban bersifat pasif. Pada penelitian ini tidak menganalisis kemungkinan adanya pengaruh karakteristik responden dan faktor lain pada masing-masing lokasi penelitian sebagai variabel pengganggu .

Pada penelitian diketahui bahwa pengetahuan dan sikap remaja pada lokasi Urban lebih tinggi dibandingkan dengan Sub Urban. Ada perbedaan sikap perilaku seksual antara remaja di perkotaan dan di pedesaan, sikap remaja di desa lebih mendukung perilaku seksual dibandingkan dengan remaja kota. ${ }^{3}$ Melemahkan pengawasan sosial pada masyarakat pesdesaan dipengaruhi oleh masukknya arus informasi melalui teknologi hingga ke pelosok desa, arus informasi tersebut berdampak pada melunaknya sikap masyarakat terhadap batasanbatasan perilaku seksual pada pergaulan remaja. 6 Berkurangnya peran tokoh masyarakat dan tokoh agama di pedesaan berkaitan dengan gaya hidup dan perilaku seksual remaja juga mempengaruhi sikap remaja di pedesaan.

Remaja yang tinggal di wilayah perkotaan lebih mudah mendapatkan akses tentang pendidikan pendidikan seksual, kemudahan akses pada remaja di perkotaan justru meningkatkan perilaku positif tentang seksualitas. Berdasarkan hasil penelitian dan teori pendukung dapat disimpulkan bahwa pengetahuan dan sikap remaja di lokasi Urban lebih tinggi dibandingkan dengan Sub Urban. ${ }^{8}$

\section{KESIMPULAN DAN SARAN}

Ada perbedaan pengetahuan dan sikap remaja Sekaa Teruna Teruni tentang perilaku seksual berisiko antara daerah Urban dengan Sub Urban tentang Perilaku Seksual Berisiko. Berdasarkan hal tersebut maka program edukasi kesehatan reproduksi berkaitan dengan perilaku seksual berisiko pada remaja Sekaa Teruna Teruni di wilayah Sub Urban perlu ditingkatkan. Penyebarluasan informasi kesehatan reproduksi melalui Sekaa Teruna Teruni dalam bentuk program kerja Sekaa Teruna Teruni di daerah Sub Urban adalah solusi untuk meningkatkan pengetahuan dan sikap remaja tentang perilaku seksual berisiko. Saran untuk peneliti selanjutnya agar melakukan identifikasi dan kontribusi pengaruh variabel lain terhadap pengetahuan dan sikap remaja tentang perilaku kesehatan reproduksi.

\section{DAFTAR PUSTAKA}

1. Baron. R.A. \& Byrne. D. 2003. Psikologi Sosial Edisi Kesepuluh Jilid 2. Jakarta: Erlangga.

2. BPS. 2018. Angka Partisipasi Kasar (APK) Propinsi Bali Menurut Jenjang Pendidikan dan Kabupaten/ Kota, 200-2018. diakses dari https://bali.bps. go.id/dynamictable/2018/02/26/247/angkapartisipasi-kasar-apk-provinsi-bali-menurut-jenjangpendidikan-dan-kabupaten-kota-2000-2017.html, diakses 10 Oktober 2019.

3. Chandra. 2015. Perbedaan Sikap Terhadap Perilaku Seksual Antara Remaja yang Tinggal di Kota Dengan di Desa. Skripsi. Program Studi Psikologi Jurusan Psikologi Fakultas Psikologi Universitas Sanata Dharma Yogyakarta.

4. Dewi. 2017. Peran Sekaa Teruna Dalam Mensosialisasikan Nilainilai Akuntabilitas Berbasis Kearifan Lokal Tri Hita Karana (Studi Kasus pada Sekaa Teruna Taruna Jaya Desa Pakraman Bangkang Baktiseraga Kecamatan Buleleng Kabupaten Buleleng Provinsi Bali Tahun 2016) e-Journal S1 Akuntansi Volume: 7 No: 1 Tahun 2017 Universitas Pendidikan Ganesha.

5. Huda. 2013. Pertumbuhan Fisik Dan Perkembangan Intelek Usia Remaja. Al-'Ulum; Vol. 2, Tahun 2013

6. Indrayani. 2016. Perilaku Berpacaran Pada Remaja Di Desa Batubelah Kecamatan Kampar Kabupaten Kampar. Jurnal. JOM FISIP Vol. 3 No. 1 - Februari 2016. Jurusan Sosiologi Fakultas IImu Sosial Dan IImu Politik Universitas Riau, Pekanbaru.

7. Mahendra. 2016. Optimalisasi Peran Sekaa Teruna Teruni (Organisasi Kepemudaan) Berbasis Kearifan Lokal Di Bali) Dalam Mendukung Terwujudnya Sistem Tata Kelola Pemerintah Desa Yang Baik Melalui Gerakan "Stt Kawal Desa”. Karya Tulis Ilmiah. Denpasar: Fakultas Hukum Universitas Udayana.

8. Rejeki.2010. Hubungan Pengetahuan Dan Sikap Remaja Tentang Reproduksi Dengan Perilaku Seks Pranikah di Konveksi Desa Jabung Kecamatan Plupuh. Jurnal Kebidanan. Vol. II, Nomor 02. 12-21.

9. Safira. 2016. Perbedaan Pengetahuan dan Sikap Kesehatan Reproduksi Remaja Urban dan Rural Kabupaten Lamongan. Paper. Surabaya: Pendidikan Geografi, Fakultas IImu Sosial dan Hukum, Universitas Negeri Surabaya. 
10. Vilayanti. 2018. Hubungan Antara Rasa Komunitas dan Komitmen Organisasi Dengan Kohesivitas Kelompok Pada Anggota Sekaa Teruna-Teruni di Badung. Jurnal Psikologi Udayana2018, Vol.5 , No.1, 158-172 ISSN: 23545607 Program Studi Psikologi, Fakultas Psikologi, Universitas Udayana.
11. Windia. 2012. Kedudukan Awig-Awig Dalam Masyarakat Hukum Adat. Makalah. Disajikan dalam Pelatihan Penyusunan Awig-Awig diselenggarakan Pusat Kajian Perempuan dan Anak. Denpasar: Fakultas Hukum Undiknas. 